Global Conferences Series:

Social Sciences, Education and Humanities (GCSSSEH), Volume 3, 2019

The $1^{\text {st }}$ International Conference on Education, Social Sciences and Humanities

DOI: https://doi.org/10.326/hum0198

\title{
Management of Nagari Tourism Based on Local Wisdom
}

\author{
Akmal $^{1}$, Henni Muchtar ${ }^{2}$, Zaky Farid Luthfi ${ }^{3}$ \\ 1,2,3 Universitas Negeri Padang \\ akmalmarlis@gmail.com
}

\begin{abstract}
The purposes of the study of the Kapujan and Nagari Nagari PPNB activities in the Sungai Nyalo Mandeh in Pesisir Selatan are: to strengthen preparation for tourism nagari: a) The first year Nagari Regulation was made in welcoming tourism guests in Nagari community, (b) second year nagari government competency development, and c) Strengthening customary institutions (KAN, adat leaders, Tungku Tigo Sajarangan, tribes, clans and other traditional symbol structures) in positions or roles as tourism nagari. This method used: technical guidance was given to participants according to their needs, workshop, practice, design regulations, models, guidebooks, property rights, articles, contained in print media. Other approaches used: in accordance with the method offered, then practice with simulations, participants see skills in using the material provided, complemented by the Communicative Reflective Motivation Approach through phases: Experimenting Phase / Case, Brainstorming Phase Ideas, Deepening Phase or Analysis Case, and Integrated Synthesis Phase. The result of the activity as an achievement was $100 \%$ in the manufacture of tourism businesses
\end{abstract}

Keywords : Management, Nagari Tourism. Kapujan, Sungai Nyalo, Local Wisdom

\section{Introduction}

The results of research by Hibah Bersaing X (Akmal, 2001-2003) regarding the violation of traditional cultural and rights identities in West Sumatra, HB XIV Akmal (2007) on the Model of Protection of Minangkabau Customary Law Communities. The results of the Padang Center of Human Rights Study Center (2014) study that the level of prosperity and security (Prosporety and Security) of the nagari community in Pesisir Selatan Regency is relatively low, their assets (ulayat) are easily released to investors. this condition is influenced by the absence of nagari regulations, the low capacity of the nagari government apparatus, and the weak functioning of customary institutions. Furthermore, the results of the study by Azwar Ananda et al (2014) on Analysis of Regional Regulations, need to be born in the model of making local regulations and nagari regulations. Akmal's research results (2016-2017) on the mapping of Radicalism recommended that it is necessary to increase the competence of nagari devices and traditional institutions to promote the welfare of the nagari community. For IbM Hendra Naldi's

Copyright $\odot 2019$, the Authors. Published by Redwhite Press.

Page | 71

This is an open access article under the CC BY-NC license

(http://creativecommons.org/licenses/by-nc/4.0). 
(2017) dedication that the traditional value system and traditional values stagnate, it is not adhered to by the nagari community, it is necessary to continue the training on strengthening traditional institutions and improving the nagari devices, and making nagari regulations. The same thing for the Nagah Nyalo river village as a result of Ibm activities Siti Fatimah (2017) pointed out that in order to strengthen tourism nagari, nagari regulations are needed, strengthening nagari institutions and traditional nagari institutions.

Based on preliminary study data and profiles of the Kapujan and Nyalo Rivers nagari conditions be follows:

According to data, Pessel Dalam Angka (2017), that the Kapujan village has been established by tourism nagari by Pesisir Selatan District, located in the Bayang Subdistrict of Pesisir Selatan Regency with borders: North borders Nagari Puluk-Puluk, Selatan with nagari Koto Baru. East with nagari Kapencong Lubuk Gambir, West with nagari Koto Berapak. (Source: Office of Wali Nagari Kapujan, 2017). The distance to the district's mother is around $9 \mathrm{Km}$, while the capital of the district is more than 24 $\mathrm{km}$. The population is 300 families, consisting of several jorong

Livelihoods are mostly as farmers, plantations, and traders as well as formal sectors such as civil servants, cooperative employees, teachers, artisans, and processors of candied nutmeg. Income, among others: rice, secondary crops and rubber, cinnamon, and nutmeg has the potential to be a superior tourist product. At the beginning of the study many traditional values were abandoned and needed to be registered as local wisdom, leading in 2017 in accordance with the proposal of the two kenagarians to form tourism tourism development in the regulation of nagari regulations (Pernag). The principles of making tourism have not been well understood, and need to have several examples of regulations.

For Nagari Sungai Nyalo is located in Koto XI Subdistrict, Pesisir Selatan Regency, which has been designated as a West Sumatra tourist area. Distance to the capital of the sub-district is around $15 \mathrm{Km}$, while the capital of the regency is more than $40 \mathrm{~km}$. The population is 700 people, consisting of several jorong. Livelihoods are mostly seafarers, plantations, and traders as well as formal sectors such as cooperative employees, teachers, and artisans. Income, among others: fish and coconut has the potential to be a superior tourist product. At the beginning of the study there were many behavioral deviations in welcoming tourist guests, customary values began to be abandoned and need to be registered as local wisdom, leading In 2017 in accordance with the proposal of the two kenagarian communities to form tourism nagari development in the regulation of nagari (Pernag) regulations. The principles of making tourism have not been well understood, and need to have several examples of tourism (Nagari Sei Nyalo Documentation Data, 2017, Siti Fatimah Service Report, 2017

The Importance of Nagari Regulations ForTourism Nagari

Nagari tourism is a social engineering, in managing tourism nagari, so that the phenomenon that occurs can be used to organize tourism nagari. According to Scot Davidson in Mardiansyah (1998) the regulation is explained in theory, namely: (1). natural law theory, (2). positivism approach, (3). antiutilitarian theory, and (4) legal realism theory. In addition, it is also used the theory of Karll Liewellyn and Roscoe Pound which suggests that rights will emerge as the final product of the process of interaction carried out by law, and thus will reflect the moral of society that always prevails. This view was perfected by Myres Mc Dougal in Mardiansyah (1998) who developed an approach to human rights that was full of values and oriented to wisdom based on noble values, protection of human dignity.

The method approach uses reflective communication methods developed by Hariyadi (2000), namely methods that encourage participatory learning processes that are centered on the audience. The aim is to encourage the ability of the nagari community and government to be based on what they have so that there is a self-learning process and in groups, through: reflection - and - action, and - self-correction, 
solitude - and - in groups, and personal experience - and - community. The participatory learning process is meaningless for the efforts of the community and the nagari government to be active and happy in activities, simulations, games, games or role playing centered on the community and the nagari government. Experience is the material of learning, through experience. According to Nadj. (2000) fostering critical power in legal education is needed to build legal awareness for all citizens. The form of critical power can be done by reviewing and discussing cases of norm violations

\section{Legal Socialization Concept}

Law or a policy is intended to shape the behavior of the community to achieve an atmosphere and certain conditions, in this case

law is seen as a tool of social engineering (a tool of social engeneering). The problem of positive legal impact actually concerning effective law: meaning, if the law is said to be effective, then there is a positive legal impact (Soekanto, 1986).

As a method, the law can contain orders, prohibitions and or permits. Suruhan and prohibition are imperative laws, while skills are objective. The method of imperative law is a priori that is binding, so it must be obeyed, while the one that is objective is a priori not binding. In the context of socialization and legal training that is the target is how to make the law have an impact on human behavior. This means that in terms of the main subject matter is how the law can be obeyed and followed by the public and government officials. In order to achieve these objectives, it is necessary to fulfill several conditions which are requirements so that the law has a positive impact. this review in Indonesia has so far received little attention, so that the application of laws and regulations often engages in large social costs both directly and indirectly which result in legal authority.

The condition in question is that the law must be communicated. Communication here is defined as the process of delivering and receiving symbols that contain certain meanings. Legal communication is mainly focused on attitudes or behaviors that manifest in real action. Therefore it contains cognitive, affective and conative components. Cognitive contains perceptions of the surrounding conditions that are covered by knowledge, affective associated with positive and negative judgments and conative relating to the tendency to act or not act on something (Soekanto, 1986).

The same thing was expressed (Shad Saleem Faruqui, Soetandyo Wigjosoebroto in Dynamics (volume 1, No. 1, May-October 1997), Meriam Budiardjo (1991), Paul S Baut and Benny Harman K (1988). The concept of customary law which contains rights arrangements human basis is used by the book "Short and Customary Minangkabau History" by M Rasyid Manggis (1971), and the book "The Basics of Minangkabau Customary Philosophy by Nasrun (1971), which explains that the source of power in Minangkabau is two, namely takambang nature to become a teacher and a Kitabullah -Qur, an), which also respects human dignity and dignity.

Strengthening Customary Nagari and Institution Institution Institutions

The Nagari Devices Institute includes, the Nagari secretary, all members of the Kaur team (Head of Affairs) in the fields of government, development, social affairs, and community security. Existing human resources are still weak in all villages in West Sumatra (Results of the West Sumatra Regional Government DPMD Documentation, 2017). According to the results of a study by Pusham UNP (2016), the weaknesses of the nagari's human resources include: poor understanding of Main Duty and Function. 


\section{Method}

The spots and workshops provided to participants are tailored to the needs. Approach used: according to the method offered, then practice with simulations, participants see skills in using the training provided, equipped with approaches:

1. Experience / in depth Case Phase)

2. Collecting Ideas Phase

3. Reflective Communicative Method Approach

4. Expansive or Case

5. Analysis Phase

6. Integrated Synthesis Phase

The progress achieved in this service are:

1. There have been various cases of the Ranpernag Nagari Kapujan Bayang and the nagari of the Nyalo River

2. The Ranpernag guidelines for cultural identity have been arranged as tourist colors

3. Service permits from the Pesisir Selatan District National Unity Agency and Nagari Government together with other devices have been arranged.

4. The purpose of service that has been achieved is:

a. Increased understanding knowledge of the tourism ministry

b. Increased skills of the community and the nagari government understand the making of regulations and other regulations

c. The ambition of the abilities and skills of the community and the nagari government in knowing tourism management by utilizing the regulations of the Ministry of Religion.

\section{Result And Discussion}

Based on the results of interviews and brainstorming and observations before conducting training there was an increase in knowledge of understanding the regulations, namely the tourism management Ranpernag. An overview of the level of community understanding of tourism management regulations after being given training:

Training activities for people who experience regulatory problems in Kapujan and Nyalo River, South Coastal District are held from June to October 2018, and will be continued in the following month, attended by all nagari devices, traditional leaders, youth, Bundo Kanduang, 30 participants. The condition of the level of understanding of participants after training can be seen in the following table:

Tabel 1

Frequency and Peercentage of People's Understanding about Tourism Management Nagari Regulation Plan

\begin{tabular}{|cccc|}
\hline No. & Respondence Answers & F & $\%$ \\
\hline 1 & Really Undersrand & 8 & 26,66 \\
2 & Uunderstand & 11 & 36,66 \\
3 & Quite Understand & 9 & 30,00 \\
4 & Not Quite Undertsand & 2 & 6,00 \\
5 & Not Understand & 0 & 0 \\
\hline & Total & 30 & 100,00 \\
\hline
\end{tabular}

Soource : Primer Data Analysis, 2018 
Basically the tendency of participants to feel helped, which so far has only been heard about tourism management, has now become a legal regulation that can be a reference in tourism. Based on data collected through 30 participants revealed in the following table:

Tabel 2

Frequency and Percentage of Participants and Their Impressions on Tourism Nagari Regulation Plans

\begin{tabular}{|llll|}
\hline No. & Respondent answers & F & $\%$ \\
\hline & Really Helping & 10 & 33,33 \\
1 & Helping & 8 & 26,66 \\
2 & Quite Helping & 12 & 40,00 \\
3 & Not Quite Helping & 0 & 0 \\
4 & Not Helping & 0 & 0 \\
\hline 5 & & 30 & 100,00 \\
\hline
\end{tabular}

Based on the explanation of the chapters of progress progress, it can be concluded:

a. The aim of this service is that $80 \%$ has been going well, starting from managing administration services, investigating cases for the compilation of Ranpernag's tourism management academic manuscripts.

b. The level of understanding in solving tourism management problems can be improved, including skills to solve tourism problems.

c. The deepening of the discussion of results or achievement targets is still being carried out, as well as preparing a draft nagari regulation (Ranpernag) about models or tourism management measures

d. This service involves students, and adds lecturers who are involved in this activity Considering the progress of service, there are several recommendations put forward, including:

a. Need for tourism management guidelines that are fairer based on local wisdom

b. For traditional Minangkabau, they are mutually nagari. The formulation will have a special statement in certain matters. As we found out in between the Nagari of Kapujan and Sungai Nyalo

c. It is necessary to revive the functions of customary justice with various levels, and by clarifying institutional duties and mutual energy.

d. tourism management needs to align all institutions and surrounding communities by paying attention to the spirit of the ABSSBK under the umbrella religion and the Pancasila 
RedWhitepress Gibal Conferences Series: Social Sciences, Education and Humannities (GCSSSEH), Volume 3, 2019

\section{References}

Pesisir Selatan Dalam Angka (2017). Bappeda. Painan

Kanwil Hukum Dan HAM (2016). Metode Penyuluhan Hukum Bagi Masyarakat. Padang.

Akmal. (2002). Model Sosialisasi Undang-Undang HAM (UU No.39 Tahun 1999) Dalam Rangka Pemberdayaan Masyarakat Daerah Sumatera Barat. Hasil Penelitan Hibah Bersaing X/1 Tahun 2002: Padang

Akmal. (2002). Kajian Profil Sumberdaya Manusia Guna Menysusun Program Pendidikan dan Latihan Dalam Meningkatkan Kualitas Penyelenggara Pemerintahan Nagari. Makalah Dialog Pada Pusham UNP: Padang.

Departemen Pendidkan dan Kebudayaan. (1983). Sistem Gotong Royong Dalam Masyarakat Pedesaan Daerah Sumatera Barat.: Proyek Inventeraisasi dan Dokumentasi Kebudayaan Daerah: Jakarta

Departemen Kehakiman. (1983). Pola Dasar Penyuluhan Hukum dan Pola Operasional Penyuluhan Hukum. Badan Pembinaan Hukum Nasional: Jakarta.

Gusnita. (2002). Usaha-Usaha Pemerintah Daerah Kabupaten Solok Kembali Ke Nagari dalam Pelaksanan Otonomi Daerah. Skripsi. FIS UNP: Padang

Kabag Pemerinatahan Nagari. (2012). Jumlah Pemerintahan Nagari di Kabupaten Pesisir Selatan. Pemda Kabupaten Pesisir Selatan: Painan

Kartasasmita, Ginandjar. (1997). Administrasi Pembangunan Perkembangan Pemikiran dan Praktiknya di Indonesia. LP3ES: Jakarta.

Koswara. E. (2000). Birokrasi dalam Era Globalisasi. Jurnal Ilmu Pemerintahan. Edisi 10, MIPI: Jakarta

Navis, A.A. (1984). Alam Takambang Jadi Guru. Adat dan Kebudayaan Minangkabau.

Grafiti: Jakarta

Pusham UNP. (2002, dan 2014). Profil Sumber Daya Manusia Penyelenggara Pemerintahan Nagari di Sumatera Barat. Laporan Hasil Penelitian Balitbang dan BPM Propinsi Sumatera Barat: Padang.

Sekda Provinsi Sumatera Barat (2016). Nama Nagari dan Keluruhan Dalam Propinsi Sumatera Barat. Biro Pemerintahan Nagari. Padang

Sianipar, M.G. (1984). Pendidikan Politik Bangsa. Sinar Harapan: Jakarta.

Simamora, Hendry. (1997). Manajemen Sumberdaya Manusia. STIE YKPN: Jakarta.

Soekanto. (1986). Beberapa Cara \& Mekanisme dalam Penyuluhan Hukum. Paradnya:Jakarta.

Stoner, James A. (1981). Management. Prentice-Hall International Inc: London.

Tim LP2M UNP. (2017). Hasil Kajian Pembangunan Nagari. Dialog Kerjasama LPM UNP dengan Pemda Kabupaten Solok Selatan: Solok Selatan

Thalib, Syofyan. dkk. (2004). Eksistensi, Hak, dan Dasar Hukum Masyarakat Hukum Adat. Hasil Penelitian Divisi Pengkajian dan Penelitian Komnas HAM Perwakilan Sumatera Barat: Padang

Monografi Kenagarian Di Kabupaten Pesisir Selatan. (2017)

Tim LP2M UNP (2015-2017). Laporan Nagari Binaan Pauh Duo Nan Batigo Kabupaten Solok Selatan

Tim LPM UNP (2012-2014). Laporan Nagari Binaan Barung Barung Belantai Kabupaten Pesisir Selatan.

Manan, Bagir. (2001). Perkembangan Pemikiran dan Pengaturan Hak Asasi Manusia di Indonesia. Hasil Penelitian. Yayasan HAM, Demokrasi dan Supremasi Hukum . PT Alumni. Bandung

M.Saad, Hasballah. (2000). Hak Asasi Manusia dan Demokratisasi Dalam Pendidikan. Makalah Pada Konvensi Nasional Pendidikan Indonesia IV 19-22 September 2000 di Hotel Indonesia: Jakarta.

Mardiansyah, Arrohman. (1998). Perspektif Perjuangan Penegakan HAM di Indonesia (Studi Tentang Kemandirian Komnas HAM 1993-1997). Hasil Penelitian. Fisipol UGM. Yokyakarta.

Mertokusumo, Sudikno. (1986). Mengenal Hukum. Liberty. Yokyakarta.

Nasrun. (1971). Atom Takambang Jadi Guru. Padang

Paul S Baut dan Benny Harman K. (1988). Komplikasi Deklarasi Hak Asasi Manusia. YLBHI. Jakarta.

Soekanto. (1986). Beberapa Cora \& Mekanisme dalam Penyuluhan Hukum. Paradnya: Jakarta. 
RedWhitepress Global Conferences Series: Social Sciences, Education and Humanities (GCSSSEH), Volume 3, 2019

Undang-Undang Dasar 1945

Undang-Undang No.39 Tahun 1999

Piagam PBB

Instrumen HAM Internasional yang telah Diratifikasi Pemerintah RI

Ketetapan MPR RI No.XVJJ Tahun 1998

Keputusan Presiden No.50 Tahun 1993

Keputusan Presiden No. 129 Tahun 1998

Kabupaten Pesisisr Selatan Dalam Angka (2005)

Dokumen Hasil Musrebang Kabupaten Pesisisr Selatan (2006) 